Ryan, Curtis R., and Jillian Schwedler. (2004) Return to democratization or new hybrid regime?: the 2003 elections in Jordan. Middle East Policy 11:2 (Summer 2004), p. 138-151. (ISSN: 1061-1924) Published by Wiley-Blackwell. The definitive version is available at www3.interscience.wiley.com]. DOI: 10.1111/j.1061-1924.2004.00158.x

\title{
Return To Democratization or New Hybrid Regime?: The 2003 Elections in Jordan
}

\author{
Curtis R. Ryan and Jillian Schwedler
}

\begin{abstract}
ARTICLE
"(Democratization) is like the story of the Huba Huba tree. There are two prerequisites for its growth: soil and climate. . . . If these are not both present, then look for any other tree to emerge . . . but not the Huba Huba."

- Jordanian parliamentary official, February 1993
\end{abstract}

In the summer of 2003, election fever

hit Jordan. Throughout the country, citizens hotly debated the outcome of the upcoming poll and hung photos of their favorite candidate in cars and shop windows. Enthusiasm crossed class, sectarian and regional lines, illustrating that Jordanians would indeed turn out to vote when motivated. More than 5.5 million votes were cast throughout the country, many at considerable personal cost to the voters. On August 18, typically noisy stores, restaurants and street corners fell silent as the results were announced. Shouts of joy and dancing in the streets followed moments later, as Jordan's Diana Karazon defeated Syria's Ruwaida Attieh to win the Beirut-based SuperStar contest, the Arab world's answer to American Idol. 1 
Just two months earlier, Jordanians

also turned out - in much smaller numbers

- to vote in their national parliamentary

elections, the fourth contest held since political re-liberalization was launched in 1989. Although the government reported a 57-percent turnout - a record high in recent years - the general apathy toward that poll resulted from a steady deterioration of the political climate in Jordan over the past decade, particularly since the delay of the elections originally scheduled for November 2001 and in the climate of the second intifada in neighboring Israel/ Palestine. Jordan had embarked on an ambitious process of political and economic liberalization in 1989, heralding the reforms as the most extensive democratization program in the region. While the post-1989 process allows for competitive elections, some level of pluralism and the emergence of civil society, opposition parties and groups have voiced considerable - and well-founded - concern regarding the state of liberalization in the kingdom. Especially since the signing of the 1994 peace treaty with Israel, the monarchy has become steadily less tolerant of the levels of pluralism, civil society and dissent that had flourished in the atmosphere of 1989-93.2 Prior to 1989, King Hussein had only sporadically supported periods of highly limited political liberalization. Even then, political openings were, as they are now, largely defensive and always cautious. When the regime was surprised by the electoral successes of the opposition in the 1989 elections - in which Islamists won some 40 percent of the seats and opposition parties together held some 60 percent of the assembly - the government responded with a new elections law that favored rural and pro-regime areas, largely at the expense of Islamists. In the late 1990s, the regime promulgated a series of new and more repressive laws on press and publications in a clear attempt to rein in a media that the regime felt had overstepped its bounds. 3 This process of deliberalization continued even after the 
succession in the monarchy itself, from the long-serving King Hussein (1953-1999) to his eldest son, King Abdullah II.

The new king dissolved the parliament two years later, in 2001. During the subsequent two-plus years during which parliament was absent from Jordanian public life, the king ruled instead by decree, largely through the office of the prime minister. The regime passed some 250 emergency and temporary laws (many reining in liberalization still further), more than it had from independence in 1946 until 2001. Jordanians also saw a series of delays as the elections scheduled for November 2001 were postponed repeatedly. When the elections did finally occur on June 17,2003 , many questions remained unanswered. As the first elections to take place since 1997, the first since the dissolution of parliament in 2001, and the first under King Abdullah II, did these elections mark a return to meaningful democratization in Jordan? Or were they merely a cosmetic exercise to placate the opposition and please international creditors? This paper provides an analysis of Jordan's 2003 parliamentary elections in an effort to answer these questions. After examining the overall liberalization process from 1989 to 2002, we explore the delays in the fourth round of national elections and the 2003 elections themselves and their implications for democratization. 4 We argue that political de-liberalization in Jordan is largely the result of regime insecurity and a perceived need to placate what it sees as essential allies: the United States and Israel. However, the manipulation of the electoral system is not merely preventing democratic processes from moving forward; it is further entrenching existing elites and alienating political moderates in ways that are likely to make a restarting of the process in the future more difficult. In this connection Jordan looks less like a stalled democratic transition than an entirely new kind of hybrid regime, neither typically authoritarian nor meaningfully democratic. 


\section{POLITICAL LIBERALIZATION, 1989-2002}

In recent years, scholars have increasingly noted that many of the states that had begun "transitions" to democracy had not moved far along that path. Although Huntington's much-touted analysis of "Third Wave" democratic transitions failed to include cases from the Arab world,5 scholars of the Middle East produced a vast literature on the broad and significant trend toward political liberalization begun by many states in the region. 6 Considerable attention was directed at exploring the compatibility of Islam and democracy, with most scholars agreeing that the large number of Islamist groups already engaging in pluralist politics provides sufficient evidence to argue that there is no necessary incompatibility. 7 While there is of course no reason to believe that all Islamist groups will be equally supportive of democratic and pluralist reforms, the main obstacles to continued progress toward democratization in the region turned out to be the regimes themselves. Initial openings often included liberalization of the press, the introduction of elections (often including the legalization of political parties), and the adoption of the language of democracy by almost all political actors, including sweeping promises of democratization by regimes as diverse as those of Jordan, Kuwait, Morocco and Yemen. Even Saudi Arabia introduced an appointed consultative council in the early 1990s. Regimes described their polities as "democratizing," but none has even approached a state of consolidation.

By the mid-1990s, it became evident that few of these processes would live up to their promises, as openings were reversed or manipulated in ways that made talk of progress toward democracy ridiculous. What the region witnessed was not a retreat to authoritarianism, but the emergence of entirely new kinds of nondemocratic 
regimes. Thomas Carothers

and Daniel Brumberg, among others, have

called for the exploration of these new

kinds of hybrid regimes, including comparative

studies of their characteristics and the

processes that led to their emergence. 8

We argue that Jordan is an example of a new sort of hybrid, one in which the regime continues to proclaim its commitment to democratization while elected parliaments are made increasingly irrelevant to governance and political freedoms are harshly constrained.

The kingdom initiated the muchheralded program of political and economic liberalization in 1989 following riots and demonstrations in southern Jordan. Citizens protested not only against the social pain associated with an International Monetary Fund austerity program, but also against corruption and nepotism in government. Stunned by the public outcry, King Hussein initiated the liberalization program in an attempt to stabilize the country and restore public support for the regime.9 In the first several years of the program, liberalization included easing government controls over the media and restoring parliamentary life and electoral democracy for the lower house of parliament.10 In those first elections, the Muslim Brotherhood was the best-organized group in the kingdom, especially since political parties had been formally banned since the late 1950s. Although the Brotherhood was registered as a charity rather than a political organization, its members nonetheless secured 22 of the 80 seats in the chamber, with 12 more going to independent Islamists. For Dr. Abd al-Latif Arabiyyat, a leader of the Muslim Brotherhood who was shortly thereafter elected speaker of the parliament, the liberalization program was long overdue and came only after the "wake up call" of the April 1989 riots:

The (liberalization) process was triggered by the need for freedom and reform. Beginning in the second half 
of the Eighties, the government exceeded its limits in many issue areas, especially economic and financial. This led to the April movement, which was a warning to the government of the importance of conducting reform. The gateway to reform was the 1989 elections.11

Those elections yielded 13 seats for leftists and pan-Arab nationalists and 33 for conservative regime loyalists, in addition to the 34 seats noted above for Islamists, giving opposition voices a clear majority. While the political opposition was energized but fragmented, many conservative regime loyalists feared for the status quo. As one cynic within the regime suggested:

Changes have more chance of survival if they are from the bottom up, not from the top down. And the changes here are from the top down. It is like a love story. One is very enthusiastic early on .... Then it is more like marriage later on. One becomes more sober and less enthusiastic as time goes on.12

Similarly, one of Jordan's former prime ministers also took pains to emphasize that Jordan's transition would involve minimal liberalization but not full democratization:

The ceiling of democracy will be raised, but the shape of the house will not change .... We are not going in the direction of the U.K. model. Jordan needs a strong central leader who will both reign and rule. . . . Still, it is not like elections in the United States, which are like a popular coup d'état every four years.13

With a strong opposition parliament and in the wake of the 1991 Gulf War, the monarchy assembled a large cross section of Jordan's political elite, including key elements of the opposition, in order to draft the Jordanian National Charter (al-Mithaq al-Watani al-Urduni). Completed in 1991, 
the document formalized the political principles of pluralism, liberalization and loyalty to the Hashemite monarchy. The regime then lifted martial law for the first time in more than 20 years and moved to legalize political parties for the first time in more than 30 years. 14 Thus in the early 1990s, Jordan's political liberalization process was clearly the most comprehensive in the entire Arab world.

With Jordan alienated from the United States, Kuwait and Saudi Arabia for its neutral stance in the 1991 Gulf War, King Hussein soon thereafter sought to rebuild those ties. Jordan's strongest card with Washington was to make peace with Israel, a process that was wildly unpopular among Jordanian citizens. The peace treaty signed in 1994 therefore came at considerable expense to political freedoms, and regime tolerance for oppositional voices and political dissent declined precipitously. The government changed the elections law just months before for the 1993 elections, switching to a one-person, one-vote system that undercut the ability of opposition voices to win seats. The previous elections law had allowed citizens a number of votes matching the number of representatives for their respective (multimember) parliamentary district. Citizens in the city of Irbid, for example, had nine representatives in parliament and hence nine votes. The new elections law ended this practice and also featured a set of uneven electoral districts that favored rural pro-regime constituencies over more urban bases of support for opposition groups from the secular left to the religious right.

The main concern for the monarchy, however, was to curb the potential parliamentary power of groups such as the Islamic Action Front (IAF), the political wing of the Muslim Brotherhood, which strongly opposed a peace treaty with Israel. In addition, secularly inclined regime loyalists were alarmed at the success of the Islamists in 1989. Summarizing the view of many within the regime, 
a high-ranking parliamentary official lamented:

The question therefore is, how can you secure democracy? I fear democracy may be a vehicle only, for one group to reach the number-one status - one group which sees all truth in one book. Then there will be room for no other book, no other view. If that happens, where will I be? It will be time for people like me to go, ... but one cannot say this here. One would be accused as a kafir or as so many Salman Rushdies. It could be the democratic path to authoritarianism.15

It was with fears such as these in mind that the regime changed the elections law prior to the next round of elections, and the strategy worked: the IAF won only 16 seats (down from the Muslim Brotherhood's 22 in 1989), while independent Islamists captured only 6 (rather than 12) seats. 16 Leftist candidates took 13 seats in 1989, but only 7 in 1993.

During the period between the 1993 and 1997 elections, political freedoms continued to decline. In spring 1997, the government introduced a harsh amendment to the Press and Publications Law, requiring all newspapers to put forth capital reserves against which violations to strict limitations would be debited. Thirteen weekly newspapers, most affiliated with opposition parties, were immediately forced to cease publication. In this increasingly restrictive climate, Jordan's opposition parties threatened an electoral boycott in 1997 unless the elections law was reformed. When no such revision took place, the IAF led an 11-party bloc in boycotting the 1997 elections, yielding a 1997-2001 parliament dominated by pro-regime conservatives, tribal leaders and very few opposition voices. The new parliament included only 6 independent Islamists, 6 left-leaning pan-Arab nationalists and an overwhelming 68 seats out of 80 for traditional tribal leaders, former government 
officials and other pro-regime conservatives.

While the left joined the Islamists

in condemning the elections law, some

sympathetic to the pro-democracy left

suggested that the new law had actually

worked in their favor, but they were unable

to see it:

Why is the Left opposed to the 1993

election law anyway? It hurt the

Islamists. They are somehow Left

without being progressive. They are

old Left. Just oppositionists as a

career. They still act like they are an

opposition in exile. They don't know

how to work inside the system, even

when they are in it.17

For another democracy activist, the problem was not just the elections law, but also the increasing role of the General Intelligence Directorate (GID), or

mukhabarat, in public life:

The 1993 election law curtailed

Palestinian and Islamist representation preceding the 1994 peace treaty (with Israel). And with the 1994 treaty the mukhabarat role actually increased in Jordan. They became stronger with the king's failing health. (Reformist prime minister) Kabariti was actually good on reforms and freedoms, but he also allowed the GID a still larger role. But (conservative prime minister) Rawabdah was absolutely awful. And (conservative prime minister) Majali, God, he's totally mukhabarat (secret police). 18

These types of charges regarding the infiltration of the intelligence services even within the liberalization program came unsolicited from several quarters, from political dissidents and democracy activists to generally pro-regime journalists and even former government ministers. One former prime minister, while praising liberalization overall, expressed several concerns, including the increased role of the mukhabarat: 
The process of democratization has reached the point of no return. The regime cannot change that. But they can and do try to contain it. They actually have strengthened the security apparatus in Jordan .... . Nothing, nothing is decided on any topic without the mukhabarat. No policy, political or otherwise, is uninfluenced by them. Probably (most) journalists are influenced by them. If there is an article, they know about it before it is printed.

The key, he argued, was to restore meaningful parliamentary life and above all to apply the rule of law, thereby curbing the power of the GID.

The 1997-2001 parliament, pliant though it was, was dissolved by King Abdullah in 2001, ostensibly in preparation for the scheduled November 2001 elections. But with large-scale protests emerging after the outbreak of the second intifada in October 2000, and again with the American attacks on Afghanistan in October 2001, government officials argued that the "climate of dissent" was a lessthanideal atmosphere for elections, even with the 1993 law still in place.19 In the parliament's absence, the palace ruled by decree, issuing more than 250 controversial temporary laws over the course of two years. Such temporary laws are permitted by the constitution in cases of national security when the parliament is not in session, and subject to parliamentary approval when the assembly reconvenes. Opposition voices contested the "urgent security necessity" of many of the laws, which clamped down on political demonstrations and created elastic measures to curb dissent both on the street and in the media. In fact, the public was unaware of more than half of these temporary laws until parliament reconvened in 2003 and the government presented some 250 laws for review.20 
In a particularly telling 2003 incident, Jordan's first elected woman parliamentarian, Tujan al-Faysal, was convicted for publishing on-line an open letter to the government. In the letter, Faysal questioned whether security issues were really at stake when the prime minister introduced a temporary law that increased insurance premiums. More controversially, she noted that the prime minister's family, which dominates the insurance industry in Jordan, stood to gain considerably from the measure. The former parliamentary representative was arrested, tried, and convicted for defaming the prime minister, the government, and the kingdom. Since Faysal is one of the most outspoken voices for liberalization and extending women's rights in Jordan, many in the pro-democracy movement understood that the act was intended to signal the regime's unwillingness to tolerate political dissent. After Faysal had served one month in jail, King Abdullah suspended the rest of the 18month sentence. But because she had been convicted of a misdemeanor in state security court - a verdict that cannot be appealed - she is now ineligible to ever again put forth her candidacy for office.

\section{POSTPONING THE 2003 ELECTIONS}

When the fourth round of elections since 1989 did not take place as expected in November 2001, opposition groups were quick to accuse the government of reversing the democratization process. The delay added another piece of evidence to the case of activists and political figure who claimed that the regime had abandoned the push toward meaningful democratization in 1993 and was no longer interested in reinvigorating it. IAF Secretary-General Hamseh Mansour put it this way: "Jordan's experiment with democracy has not really been reversed; in fact, it died in childbirth." 21 For its part, the regime claimed to have postponed the elections 
because the system of magnetized voting cards would not be ready in time. More likely, the rising regional tensions resulting from the second intifada and the U.S. invasions of Afghanistan and later Iraq led the regime to constrain public expression of political dissent via protests and the media. In this climate, the regime was uncertain as to whether elections would return the sort of opposition parliament that would challenge the regime's foreign-policy initiatives.

Expectations regarding new parliamentary elections were repeatedly dashed.

Clearly external security issues were major concerns for the regime, but the monarchy was also concerned with internal opposition, especially over the possibility of

another U.S. war on Iraq. While the 1989 protests in southern Jordan led the regime to consider liberalization, protests in December 2002 in the southern city of Maan led the government instead to crack down harshly on dissent. The regime labeled its opponents "Wahhabis," a word that has become a generic term for militant Sunni Islamists, but which more importantly implies that they are not really from Jordan.22 Similarly, civil unrest in Maan in 1998 was blamed on secular leftists who were pro-Iraqi or perhaps even Iraqi agents themselves. In these and other instances, everything from local social unrest to actual militancy is blamed on various types of "outside agitators."

In the Jordanian context, most opposition has been explicitly loyal, and indeed the regime and the Muslim Brotherhood have a long pattern of mutual understanding regarding regime loyalty and policy opposition.23 This type of pattern was codified in the 1991 National Charter, which set the stage for limited political pluralism and participation, but within the context of loyalty to the Hashemite monarchy. The tensions between the opposition and the monarchy, therefore, turn not so much on the nature of the political system, but rather on profound differences regarding specific policy choices as well as the 
desired extent of political liberalization.

Thus public anger over electoral postponements is part of the broader concern over unpopular elections laws, renewed restrictions on the media, and government bans on such democratic acts as public demonstrations. One of the temporary laws issued in August 2001 required that protest organizers obtain permission three days in advance; in practice, few permits are ever granted, and, when they are, the government often dictates the locale and even the number of protesters.24 In terms of policy, the regime is intent on maintaining its 1994 peace treaty with Israel, as well as its foreign aid and military links to the United States and the United Kingdom. Both policy areas are increasingly unpopular within Jordan and have become sources of social unrest. Political parties and professional associations have repeatedly made clear their anger over Jordan's peace treaty with Israel, while the Palestinian death toll mounted in the West Bank and Gaza. Jordan's electoral delays, therefore, must be seen not only in the context of a changing regional security environment, but also in the context of a broader liberalization beginning in 1989, and, more important, de-liberalization as the earlier process began to erode in 1993 and correspondingly Jordan's "political opening" began to close.

Thus the question of electoral delays is not the core problem but rather a symptom of the broader crisis between the government and the opposition, and indeed between the regime and Jordanian society, over the entire political liberalization process. When King Abdullah II first ascended the throne, he seemed to show 
signs of the desire to reinvigorate the liberalization process and did not hesitate to allow municipal elections to proceed apace in July 1999.25 Since then, however, regional issues have dominated the regime's agenda at the expense of political freedoms at home.

The regime's response turned not just on electoral delays, but mainly on its new campaign, dubbed "Jordan First." This slogan conveys the regime's nationalist approach and its intention to tolerate no exploitation of

divisions within

Jordanian

society -

whether

between

secularists and

Islamists or

between

Palestinians and

Transjordanians.

But the slogan

has also been read by the opposition as either avoidance of commitment to broader Arab or Islamic concerns, or as a statement brooking no dissent, and hence no democracy, within increasingly security-oriented Jordanian politics. Scott Greenwood has argued further that the regime manipulated the elections laws while pursuing economic liberalization, in order to maintain the external funding on which the kingdom is dependent and to placate two key regime constituencies: Transjordanians and the business elite. 26

Given the overwhelming pro-regime majority in the 1997-2001 parliament and the regime's efforts to suppress political dissent in the media and via protest activities, the kingdom's professional associations emerged in the late 1990s as perhaps the only real remaining locus of political opposition. The wealthier of these associations, particularly the Islamist-dominated engineers association, led the national campaign against normalization of relations with Israel.27 In this repressive climate, 
opposition parties such as the Islamic Action Front were particularly eager to return to the sphere of state-sanctioned political engagement. Thus when the government announced a firm date for the elections - June 17, 2003 - all the opposition parties expressed a willingness to participate even though they viewed the electoral system as highly flawed.

\section{PARLIAMENTARY ELECTIONS}

The 2003 elections were finally held under still another elections law, which had been announced in July 2001. The new law lowered the age of voting eligibility from 19 to 18 and increased the number of seats from 80 to 104 . The government announced that redistricting would address some of the earlier inequalities, but in fact the distribution of the additional seats maintained the advantage of the largely pro-regime Transjordanian south at the expense of the more oppositional - and Palestinian-populated - regions in and around Amman. In February 2003, King Abdullah revised the system once more with a new decree that added six additional seats intended to ensure at least minimal representation for women. In the previous three elections combined (1989, 1993 and 1997), Tujan al-Faysal was the only successful female candidate. However, she won as a Circassian running in one of the dedicated minority seats, succeeding with a few thousand votes while others lost non-quota seats with many more votes. The new women's quota was intended to guarantee that at least six women would enter the new parliament.28 While the Islamic Action Front originally opposed the women's quota, it eventually included for the first time a woman, Hayat al-Musayni, among its slate of 30 candidates. 29 No Jordanian woman won a seat outright in 2003, but Musayni won a larger percentage of votes in her district than did any other female candidate nationwide. Thus the first woman seated in the new 2003-2007 
parliament was neither secular nor feminist, as the IAF feared, but rather a

conservative Islamist activist. Five additional female candidates were also

awarded seats on the basis of percentage

of votes received in their districts.

Overall, the Islamic Action Front

succeeded in getting 17 of its party members

elected (including Musayni). Aside

from the IAF, five independent Islamists

were also elected, including such highprofile

conservative Islamists as the IAF's

Muhammad Abu Faris and former IAF

member Abd al-Munim Abu Zant, whom

the party had expelled from its ranks just

before the election. As expected, most of

the parliamentary seats went to traditional

tribal leaders or former government

officials, putting at least 62 of the 110 seats

into the hands of loyalist pro-regime

figures. The official voter turnout stood at 57 percent of eligible voters, with few mishaps or irregularities. The IAF did complain that extensive vote-rigging had taken place in the southern city of Karak, though the government responded by acknowledging irregularities but asserting that they had been caught in time and "taken care of." While the overall turnout was respectable, the numbers varied considerably across districts. Turnout in rural areas, for example, tends to be very high, while urban Palestinian-majority districts register the lowest turnouts in the kingdom, suggesting that these neighborhoods have limited confidence in the government, the electoral system and their own political efficacy.

\section{THE 2003-07 PARLIAMENT}

Following the elections, government and opposition figures alike began to speculate on what sort of parliament this would be. While the assembly is widely seen as a pro-regime body, it is not without significant - and far from timid - opposition voices. When the deputies convened for the first time, IAF deputies created a 
stir over the oath of loyalty. While they

joined all the deputies in swearing allegiance

to King Abdullah, the Islamist

delegates added that they would only do so

as long as the king ruled in accordance

with Islam. Indeed, the IAF made clear

that its participation in the elections in no

way represented its approval of the

elections laws, which it still regards as

systematically biased against Islamist and

Palestinian representation. But party

leaders argue that they decided to participate

in the electoral process in large part in

order to change it. Dr. Abd al-Latif

Arabiyyat, chair of the IAF consultative

council and former parliamentary speaker, chose not to run but nevertheless defended

the party's decision: "Our decision is

based on the strong belief that the time has

come to rectify all the wrongdoings that

have been committed by the government

over the past years." 30 For the IAF, this

includes not only the series of temporary

laws, but also the 1994 peace treaty with

Israel. On these points, most of the

secular left and nationalists agree with the

Islamists.

While Islamist and other traditional

opposition voices are certain to continue challenging the regime on these and other issues, the assembly has another possible and unexpected - opposition bloc: former government officials. These include former cabinet ministers and even former prime minister Abd al-Rauf al-Rawabdeh, whose cabinet was dismissed in 2000 and who is widely said to hold a grudge against the regime. What these individuals possess that the traditional opposition mostly lacks are high-level connections in the government, detailed knowledge of how the executive works, and - in some cases - strong and recent personal resentment. Their combination of experience and attitude could potentially create the sorts of alliances among other pro-regime deputies that Islamists and leftists are unlikely to forge.

During the extraordinary session of parliament convened from July through 
September 2003, the assembly took up the issue of examining the 250-plus temporary laws. Despite the initial indications that the opposition deputies would be obstructionist, the functioning of these first months reflected the sorts of debates of earlier assemblies. The Islamists complained about the popularity of SuperStar contestant (and eventual winner) Diana Karazon, while other deputies congratulated the government on its support of the national soccer team, which defeated Iran, to great national joy.

The temporary laws, however, suggested that an earlier, tacit agreement between the conservative, pro-regime deputies and the regime itself remained intact. That is, many have long contended that King Hussein allowed the deputies final say over many domestic issues in exchange for support for his foreign-policy programs, notably the peace with Israel and now the close relations with the United States. Government officials and opposition figures agree that this "agreement" has not been formally articulated since the days when the peace treaty was being negotiated, but many understand the bargain to still be intact.31

In this connection, among the first temporary laws to be examined were one changing the language of a law that was seen as supporting honor killings (by being lenient in sentencing those convicted of honor crimes) and one that extended citizenship to children of Jordanian mothers, a right previously given only to children of Jordanian fathers. Both temporary laws were rejected by the new parliament within the first weeks of the extraordinary session. While the king and queen have been on record strongly supporting these changes, they remained silent in the face of their defeat in parliament. In addition to the alleged, unstated agreement that the monarchy would stay out of domestic issues, others speculated that the IAF pushed to review these two laws early in the extraordinary session because they 
were the only laws for which they could mobilize support and thus win an early "victory" in the new assembly. In either case, the new assembly has done little to challenge the regime on key issues, both domestic and foreign, and therefore can be seen as an overwhelmingly pro-regime assembly.

The resumption of parliamentary life in Jordan is certainly an important step in furthering the country's political freedoms. But with the remaining restrictions on political expression and freedom of speech, the monarchy is sadly far from where it might easily have been, had it continued or even maintained the openings of the early 1990s. Indeed, Jordan in 2003 resembles not so much a country on the road to democracy as a new hybrid of the sort described as "liberalized autocracy" by Brumberg and "dominant-power politics" by Carothers.32 Each points to cases in which initial political openings mark less an advancement toward democracy than the emergence of new hybrid forms of nondemocratic rule.

\section{CONCLUSION}

Jordan's 2003 elections illustrate neither a commitment nor a lack of commitment to democratic reform in the Hashemite kingdom. Many in the government as well as in the opposition believe that the regime would like to push for further reforms but feel that either the timing is not right or the citizenry and political parties have not matured to the point at which real democratization is viable. Others argue that the regime has never been committed to meaningful political liberalization and has used the language and artifacts of democracy to legitimate its continued rule in a climate in which authoritarianism is increasingly rejected on an international as well as a domestic level. Whatever the case (and it may well be some combination of the two), we argue that the process of reversing or 
halting the political liberalization measures introduced in the early 1990s has been largely the product of regime insecurity rather than a lack of commitment to eventual reform. Perhaps more important, the regime has felt the need to placate what it sees as essential allies: the United States and Israel. Following Carothers and Brumberg, however, we also argue that the manipulation of the electoral system is not merely preventing democratic processes from moving forward; it is further enr trenching existing elites and alienating political moderates in ways that are likely to make a "restarting" of the process in the future more difficult.

As a new kind of hybrid regime, Jordan continues to locate the language of democracy centrally within its political rhetoric, as indicated by King Abdullah's speech at the first regular session of the new parliament on December 1, 2003. The king called for the dissemination of a "culture of democracy" and for a "national dialogue that will lead to convening a national congress to discuss the different economic, social and political issues, and to study viable solutions for them." The king further emphasized to the parliament his concerns for the rights of women, the independence of the judiciary, and the role of the assembly in achieving democracy in the kingdom.33

At the same time, the elected assembly has little to do with meaningful processes of governance, serving more to rubberstamp regime initiatives or as an outlet for political debate in a carefully controlled environment. Election laws and districting are manipulated to produce a majority-compliant assembly, while the senate, or upper house of parliament which must approve any legislation put forth by the elected lower house - remains a royally-appointed body. As former prime minister and former senator Taher Masri noted, there is much significance in the king's selection of former prime minister Zaid al-Rifai to head the senate.34 Rifai 
strongly opposed political liberalization in 1989 and continues to oppose it today. Likewise, the senate that began its term in January 2003 notably lacked many of the strong pro-reform voices of previous years, including Masri himself, suggesting a desire to prevent meaningful reform from emerging through the elected lower assembly. Considering this, together with the serious restrictions on expressing political dissent in the media and through public assembly, one can hardly argue that Jordan is engaged in a meaningful process of democratization, regardless of the rhetoric that emanates from the highest offices. For these reasons, and because the "reversals" are now a decade old, Jordan should best be understood as a hybrid regime, where democratic practices are present but shallow, and where power remains in essentially the same hands as prior to liberalization..

\section{FOOTNOTES}

1 The number of votes cast amounts to approximately one vote per Jordanian, indicating that many voted repeatedly despite paying a fee for each phone call to vote.

2 Laurie A. Brand, "The Effects of the Peace Process on Political Liberalization in Jordan," Journal of Palestine Studies, Vol. 28, No. 2, 1999, pp. 52-67; and Mehran Kamrava, "Frozen Political Liberalization in Jordan: The Consequences for Democracy," Democratization, Vol. 5, No. 1, 1998, pp. 138-157.

3 See, for example, Saeda Kilani, Black Year for Democracy in Jordan: The 1998 Press and Publications Law (Copenhagen: Euro-Mediterranean Human Rights Network, 1998).

4 Parts of this article draw on Curtis R. Ryan, "Liberalization and Deliberalization in Jordan," Perihelion, Online Journal of the European Rim Policy and Investment Council (ERPIC), February 2003; Curtis R. Ryan, "Political Opposition, Democracy, and Jordan's 2003 Elections," Perihelion, August 2003, online at http:// www.erpic.org; Jillian Schwedler, "Jordan's Democratic Opening and Closing," Middle East Report Online, July 2002; and Schwedler, "Occupied Maan: Jordan's Closed Military Zone," Middle East Report Online, December 2002.

5 Samuel P. Huntington, The Third Wave: Democratization in the Late Twentieth Century (Norman: University of Oklahoma Press, 1991).

6 For general collections surveying the region, see Rex Brynen, Paul Noble and Bahgat Korany, eds., Political Liberalization and Democratization in the Arab World, Volume I: Theoretical Perspectives (Boulder, CO: Lynne Rienner Publishers, 1995); Tim Niblock and Emma Murphy, eds., Economic and Political Liberalization in the Middle East (London: British Academic Press, 1993); Ghassan Salamé, ed., Democracy Without Democrats? The Renewal of Politics in the Muslim World (London: I.B. Taurus, 1994); and Augustus Richard Norton, ed., Civil Society in the Middle East, 2 vols. (Leiden: E. J. Brill, 1995-96).

7 For example, see Azzam Tamimi, ed., Power-Sharing Islam? (London: Liberty for Muslim World Publications, 1993); Laura Guazzone, ed., The Islamist Dilemma: The Political Role of Islamist Movements in the 
Contemporary Arab World (Reading, UK: Ithaca Press, 1995); John L. Esposito and John O. Voll, Islam and Democracy (New York: Oxford University Press, 1996); John Esposito, ed., Political Islam: Revolution, Radicalism, or Reform? (Boulder, CO: Lynne Rienner, 1997); Fred Halliday, Islam and the Myth of Confrontation (London: I.B. Taurus, 1997); Ahmad S. Moussalli, ed., Islamic Fundamentalism: Myths and Realities (Reading, UK: Ithaca Press, 1998); Bruce B. Lawrence, Shattering the Myth: Islam Beyond Violence (Princeton, NJ: Princeton University Press, 1998); Vickie Langohr, "Of Islamists and Ballot Boxes: Rethinking the Relationship between Islamists and Electoral Politics," International Journal of Middle East Studies, Vol. 33, November 2001, pp. 591-610; and Ahmad S. Moussalli, The Islamic Quest for Democracy, Pluralism, and Human Rights (Gainesville: University Press of Florida, 2001). For dissenting views, see Henry Munson, "Intolerable Tolerance: Western Academic and Islamic Fundamentalism," Contention, Vol. 5, No. 3, 1996, pp. 99-117; Bassam Tibi, The Challenge of Fundamentalism: Political Islam and the New World Disorder (Berkeley: University of California Press, 1998); and Bernard Lewis, What Went Wrong? The Clash Between Islam and Modernity in the Middle East (Oxford, UK: Oxford University Press, 2001).

8 See Thomas Carothers, "The End of the Transition Paradigm," Journal of Democracy, Vol. 13, No. 2, January 2002, pp. 5-21; and Daniel Brumberg, "The Trap of Liberalized Autocracy," Journal of Democracy, Vol. 13, No. 4, October 2002, pp. 56-68.

9 On the origins of democratization and liberalization in Jordan, see Rex Brynen, "Economic Crisis and PostRentier Democratization in the Arab World: The Case of Jordan," Canadian Journal of Political Science, Vol. 25, No. 1, 1992, pp. 69-97; Brynen, "The Politics of Monarchical Liberalization: Jordan," Political Liberalization and Democratization in the Arab World. Vol. 2: Comparative Experiences, eds. Bahgat Korany, Rex Brynen, and Paul Noble (Boulder, CO: Lynne Rienner Publishers, 1998), pp. 71-100; Laurie A. Brand, "Economic and Political Liberalization in a Rentier Economy: The Case of the Hashemite Kingdom of Jordan," Privatization and Liberalization in the Middle East, eds. Iliya Harik and Denis J. Sullivan (Bloomington: Indiana University Press, 1992), pp. 167-188; Mehran Kamrava, "Frozen Political Liberalization in Jordan: The Consequences for Democracy," Democratization, Vol. 5, No. 1, 1998: pp. 138-157; Marc Lynch, State Interests and Public Spheres: The International Politics of Jordan's Identity (New York: Columbia, 1999); Malik Mufti, "Elite Bargains and the Onset of Political Liberalization in Jordan," Comparative Political Studies, Vol. 32, No. 1, 1999, pp. 100-129; Katherine Rath, "The Process of Democratization in Jordan," Middle Eastern Studies, Vol. 30, No. 3, 1994, pp. 530-557; Glenn E. Robinson, "Defensive Democratization in Jordan," International Journal of Middle East Studies, Vol. 30, No. 3, 1998, pp. 387-410; Curtis R. Ryan, "Elections and Parliamentary Democratization in Jordan," Democratization, Vol. 5, No. 4, 1998, pp. 176-196; and Ryan, Jordan in Transition: From Hussein to Abdullah (Boulder, CO: Lynne Rienner, 2002).

10 Kamel S. Abu Jaber and Schirin H. Fathi, "The 1989 Jordanian Parliamentary Elections," Orient, Vol. 31, 1990, pp. 67-86.

11 Ryan interview with Dr. Abd al-Latif Arabiyyat. Amman, February 25, 1993.

12 Ryan interview at the Jordanian parliament. Amman, February 1993.

13 Ryan interview. Amman, March 1993.

14 For Jordanian assessments of the kingdom's emerging party spectrum, see Ahmad Abu Khusa, alDimuqratiyya wa al-Ahzab al-Siyasiyya al-Urduniyya [Democracy and Jordanian Political Parties] (Amman: Middle East Publishing Company, 1991); Marwan Ahmad Sulayman al-Abdalat, Kharita al-Ahzab alSiyasiyya al-Urduniyya [Map of Jordanian Political Parties] (Amman: Dar al-Ubra, 1992); Sulayman Sways, "Kharita al-Ahzab al-Siyasiyya fi al-Urdun" [A Map of Political Parties in Jordan] al-Urdun al-Jadid, 1990, pp. 122-141; Ranad al-Khatib lyad, al-Tayarat al-Siyasiyya fi al-Urdun wa Nas al-Mithaq al-Watani alUrduni [Political Tendencies in Jordan and Text of the Jordanian National Charter] (Amman, 1991). Note that each of these studies was published even before the political parties law finally emerged in 1993. It had long been anticipated. After 1993, the al-Urdun al-Jadid Research Center began publishing a series of studies of parties, elections, civil society and democracy in Jordan, including Hani Hourani, Talib Awad, Hamad alDabbas, and Amr Shanikat, eds., al-Ahzab al-Siyasiyya al-Urduniyya [The Jordanian Political Parties] (Amman: Markaz al-Urdun al-Jadid li al-Dirasat, 1993). For Jordanian assessments of the democratization process more generally, see, among others, Husayn Abu Ruman, ed., Aqd Min al-Dimuqratiyya fi al-Urdun [A Decade of Democracy in Jordan] 1989-1999 (Amman: Markaz al-Urdun al-Jadid li al-Dirasat, 2001); Sashban Khulayfat, al-Dimuqratiyya fi al-Urdun [Democracy in Jordan] (Amman: Dar Afaq, 1993); and Tariq Khuri, Mustaqbal al-Urdun: al-Dimuqratiyya, al-Huwiyya, al-Tahdiyyat [The Future of Jordan: Democracy, Identity, Challenges] Amman, 1990. 
15 Ryan interview at the Jordanian parliament. Amman, February 1993.

16 Abla M. Amawi, “The 1993 Elections in Jordan,” Arab Studies Quarterly, Vol. 16, No. 3, Summer 1994, pp. 15-27.

17 Ryan interview with Jordanian democracy activist. Amman, July 2001.

18 Ibid.

19 Jillian Schwedler, "More than a Mob: The Dynamics of Political Demonstrations in Jordan," Middle East Report, Spring 2003.

20 Most political parties and activists estimated the total number of temporary laws to be around 120-150. Schwedler interviews with activists and opposition political figures, Amman, July 2003.

21 Schwedler interview with Mansour. Amman, December 7, 2003.

22 Jillian Schwedler, “Occupied Maan, Jordan's Closed Military Zone.”

23 Marion Boulby, The Muslim Brotherhood and the Kings of Jordan, 1945-1993 (Lanham, MD: University Press of America, 1999); Quintan Wiktorowicz, The Management of Islamic Activism: Salafis, the Muslim Brotherhood, and State Power in Jordan (Albany: State University of New York Press, 2000).

24 Schwedler interviews with IAF Secretary-General Hamzeh Mansour, IAF Chair of the Shura Council Abd al-Latif Arabiyyat, former Professional Associations Complex President Muhammad Oran, and a number of independent political activists. Amman, June-December 2003.

25 On the 1999 municipal elections, see Curtis R. Ryan, "Political Liberalization and Monarchical Succession in Jordan," Israel Affairs, Vol. 9, No. 3, Spring 2003, pp. 129-140.

26 Scott Greenwood, “Jordan's 'New Liberal Bargain': The Political Economy of Regime Security,” Middle East Journal, Vol. 57, No. 2, Spring 2003.

27 The doctors', lawyers', engineers', agricultural engineers', pharmacists' and dentists' associations have been much more oppositional in their political activism than have the "poorer," more labor-oriented associations, notably the journalists' association, which is largely seen as overrun by pro-government informants.

28 If a number of women won their seats outright, their number would be subtracted from the six - if one woman was elected outright, five seats would go to those who had won the largest percentage of votes in her district. In the end, none would have succeeded without the quota system.

29 For a detailed discussion of IAF and Muslim Brotherhood positions toward female candidates, see Janine Astrid Clark and Jillian Schwedler, "Who Opened the Window? Women's Activism Within Islamist Parties" Comparative Politics, Vol. 35, No. 3, 2003.

30 “Islamic Action Front Promises Tough Stance in Parliament," The Star (Amman), July 6, 2003.

31 Schwedler interviews with government officials and opposition figures. Amman, November-December 2003.

32 Daniel Brumberg, "The Trap of Liberalized Autocracy," Islam and Democracy in the Middle East, eds. Larry Diamond et. al. (Baltimore: Johns Hopkins University Press), pp. 35-47; and Thomas Carothers, "The End of the Transitions Paradigm," Journal of Democracy, Vol. 13, No. 2, January 2002, pp. 5-21.

33 H.M. King Abdullah II, "Speech to the 14th Parliament's First Ordinary Session," Amman, Jordan, December 1, 2003. The text of the king's speech is available online as www.jordanembassyus.org.

34 Schwedler interview with Masri. Amman, June 18, 2002. 